\title{
Discovery Myths of New Zealand: Some Cultural, Historical, and Philosophical Perspectives
}

\section{Introduction}

The discovery of New Zealand, first by Polynesia and followed by Europe, have become important narratives in the nation's evolving sense of identity. ${ }^{1}$ However, these narratives are neither straightforward in themselves, nor always completely complementary with each other. The purpose of this particle is to explore some of the historical, cultural, and philosophical bases of these discovery myths, with a focus on their construction and reconstruction. What emerges from this survey is that the discovery myths are an example of history being appropriated at times for ideological purposes, and that the character and content of these myths is necessarily fluid in order to accommodate the shifting requirements for which they are employed.

\section{Conceptualising a Destination}

Before any human had set eyes on the country or even knew of its presence, New Zealand existed as an idea. Of course, the name was unknown, as was its location, and its scale and form were inconceivable both to the occupants of the small archipelagos in the South Pacific who eventually landed on its shores, and to the explorers from Europe who, centuries later, claimed New Zealand as their own discovery. However, the possibility that a significant land mass reclined at the bottom 
of the South Pacific, simply waiting to be found, was all the incentive needed for explorers to set out in search of it almost as if they were willing it to exist.

The Scottish philosopher David Hume ventured into the terrain of this imagination and concluded that people's musings influenced their thinking to a far greater extent than they realised. ${ }^{2}$ He likened the functioning of the imagination (in a metaphor appropriate for this work) as a ship which, having been 'put in motion by oars, carries on its course without any new impulse'. ${ }^{3}$ He saw the power of the imagination as extending to govern people's beliefs - 'however contrary to daily experience and observation'4 - as well as being able to mutate into a form of objectivity. ${ }^{5}$

The imagination was not seen as something that could alter an individual's memory, but it did have the capacity to produce new ideas about what had already taken place, thereby imposing a new order on past impressions. ${ }^{6}$ The scope of this imaginative influence on how people saw the world was enormous as Hume saw it: 'Nothing is more admirable, than the readiness, with which the imagination suggests its ideas, and presents them at the very instant, in which they become necessary or useful. The fancy runs from one end of the universe to the other in collecting those ideas, which belong to any subject. One would think the whole intellectual world of ideas was at once subjected to our view, and that we did nothing but pick out such as were most proper for our purpose'. ${ }^{7}$

Immanuel Kant, Hulme's German contemporary, tried to drive a wedge between imagination and reason. He considered the two mental functions to be distinct faculties, but then conceded not only that all knowledge was based on imagination, but that ideas of reason, as a consequence, could never lead to true knowledge, because such ideas ultimately were just pure intuition. ${ }^{8}$ Imagination was serious business for eighteenth-century European philosophers. It was not some diversion from the more important issues they 
considered, but an integral component in understanding human motivation. New Zealand may not have been something that 'the eye sees', but it was certainly something that 'the imagination knows'. 9

Those who acted the earliest on the impulse of the imagination to find and colonise this unknown territory were the Polynesians, for whom discoveries were part of an ongoing process of exploration and settlement that had led them prior to $1500 \mathrm{AD}$ - to be the most widespread ethnic group on earth. ${ }^{10}$ The role of imagination in this long chain of discovery was crucial. ${ }^{11}$ When Polynesians (like all other peoples) committed themselves to exploring for new places to settle, their imaginations had already travelled ahead of them. The impression of the location that formed in the mind always preceded the act of landing at the destination. ${ }^{12}$

Most of the low-latitude Pacific archipelagos were settled by humans at least a thousand years before Europeans became aware of the existence of the Pacific Ocean. Starting from China and Taiwan, the first migrants moved towards Papua New Guinea, and then around 3,500 years ago, fanned out across the Pacific Ocean, settling almost all the main island groups and possibly even reaching as far east as Central and South America. ${ }^{13}$

Distance did not lead to dissolution though. These migrants maintained the stories and imagery of their movements across the South Pacific, and the reverent rituals later attached to these narratives (recounted at the death of a great chief, for example, or as part of some solemn and cherished religious rite) ensured that they remained a fixed part of the cultures of the region. ${ }^{14}$ The imagery of voyaging even extended to the canoes used by these migrants. They went from being inanimate objects to living entities, to the point where by the time Europeans began to record Maori discovery mythology, from the early nineteenth century, the 
word tupuna (ancestor) was being used by Maori to describe both a forebear and the canoe that transported the original inhabitants to New Zealand. ${ }^{15}$

And 'canoe' does not do it justice. Since the late eighteenth century, when European explorers first encountered them, the word has been used as a shorthand for vessels that were capable of transporting over a hundred people, together with animals and plants across the Pacific. ${ }^{16}$ These waka (canoes) may have exceeded thirty metres in length 17 - immense compared to a humble dug-out log, paddled across a glassy lagoon that the word 'canoe' instinctively conjures. The waka used for exploration and then migration were almost certainly double-hulled in design, 18 although the exact form of these ancient vessels is now unknown. ${ }^{19}$ But while their size and form is open to speculation, 20 it is reasonably certain that these waka never quite attained the exaggerated proportions of the Kaahua waka from the Marquesas, which according to legend was so large that it had a number of houses on it, and bailers had to climb up the sides of the hulls from the bottom to pour out the bilge water. ${ }^{21}$

Polynesian waka were not mere modes of transport, though. They were monuments - the products of an entire community pouring its exertions into their construction, and embodying themselves in these large seagoing edifices. ${ }^{22}$ At every stage in the building of waka, sacred rites were performed, ${ }^{23}$ climaxing with their launch into Tangaroa, the god of the sea, at which point an aquatic communion commenced.

From the outset, the sense of past and the sense of place were interlaced in this culture of exploration. And so it ought to have, as the British captain and explorer John Smith argued in the early seventeenth century: 'History without Geography wandreth as a Vagrant without a certain habitation'. ${ }^{24}$ This is borne out in one of the recurring themes in Polynesian myths about creation and discovery - that of 'land-raising'.25 Stories about islands being fished up or 
thrown down by ancestors abound throughout the mythology of Polynesia, and form part of a global pattern of origin-myths in which the earth rises from the oceans. ${ }^{26}$ Niue, for example, was originally said to have been a small area of land barely protruding above the ocean when two men from Tonga Huanaki and Fao - swam 450 kilometres to reach it and then stamped on it with their feet, causing the water to run off and the land to rise (and subsequently, trees and other vegetation to grow). ${ }^{27}$ Tonga was uplifted by a messenger of the ancestral deity Tagaloa, and Ouvéa (part of New Caledonia) was raised by a youth who kept commanding it to 'go higher'. ${ }^{28}$ Similar themes of islands being raised from the sea appear in oral histories from Fiji, Papua New Guinea, the Solomon Islands, some of the Hawaiian islands, and other Pacific island groups. ${ }^{29}$

Tagaloa occasionally got credit for land-raising, but in most of the myths, it was Maui (variously his son or step-son) who was responsible for fishing up islands. By the time the early European visitors to the Pacific began to trawl the region for origin-myths, the story of Maui fishing up land existed in the Cook Islands, Micronesia, French Polynesia, Hawaii, Niue, Tokelau, Tonga, Vanuatu, and New Zealand. 30

It is perhaps a testament to the tenacity with which ancient Polynesians clung to these origin-myths that the Maui story survived for centuries in numerous communities isolated from each other by thousands of kilometres of ocean with remarkably little deviation from its basic dramatic elements. At the core of the myth is the precocious trickster Maui, generously imbued with supernatural powers, who drops a magical fishing hook and line into the sea from his boat - often at a designated point - and then hauls up a land mass. Sometimes the land is portrayed initially as being a giant thrashing fish which is subdued and killed by this virile demigod. Maui then variously shapes the country, populates it with humans, or covers it with vegetation. ${ }^{31}$ 
These myths were cherished parts of Polynesian culture, and were transmitted down the generations like 'a long chain of interlocking conversations between members of the group', 32 producing the sort of history that Emile Durkheim described as the priceless instruments of thought which the human groups have laboriously forged through the centuries and where they have accumulated the best of their intellectual capital'. ${ }^{33}$ Yet, however priceless and ancient these myths may have been, and however much of Durkheim's intellectual capital they may have accumulated, their isolation - the very ingredient that prevented their contamination - led to them losing much in the way of resilience to outside influences. ${ }^{34}$ So when an outsider culture finally arrived, the effects were profound. From the late eighteenth century, Maori history became popularly understood as being whatever could be observed from the European vantage point. Those fragments that remained concealed in the crevices of traditional Maori society - particularly the more secretive or tapu elements of its oral tradition - were therefore classified as either 'unknown', or 'lost' until such time as they could be captured and put down on paper. For most of the nineteenth century (and arguably later as well), the European notion of Maori history was popularly regarded as whatever had been recorded in books. Apart from that, there was no Maori history - a belief reminiscent of Hugh Trevor-Roper's notoriously myopic assertion in relation to African history, that 'Perhaps in the future there will be some African history to teach. But at the present there is none; there is only the history of Europeans in Africa. The rest is darkness, and darkness is not the subject of history'. ${ }^{35}$

Not that Trevor-Roper was the first person to articulate this thought. In the early nineteenth century, Hegel had set the tone for the interpretation of indigenous, non-European history, with his assault on Africa culture, and the limited state of intellectual evolution that the continent's inhabitants had supposedly reached: 
In Negro life the characteristic point is the fact that consciousness has not yet attained to the realization of any substantial objective existence-as for example, God, or Law-in which the interest of man's volition is involved and in which he realizes his own being. This distinction between himself as an individual and the universality of his essential being, the African in the uniform, undeveloped oneness of his existence has not yet attained; so that the Knowledge of an absolute Being, an Other and a Higher than his individual self, is entirely wanting. The Negro, as already observed, exhibits the natural man in his completely wild and untamed state. We must lay aside all thought of reverence and morality-all that we call feeling-if we would rightly comprehend him; there is nothing harmonious with humanity to be found in this type of character. ${ }^{36}$

It was all too easy to allow this condescending and racist impression of non-European cultures to seep into the treatment with which Maori history received at the hands of some nineteenth-century writers. Admittedly, it seldom got not nearly as bleak as Hegel's outright dismissal, but it frequently got far too close.

Each subsequent generation of scholars which deferred to the early texts on Maori history inevitably placed their own interpretations on the European versions of these histories that they almost exclusively relied on. ${ }^{37}$ Maori history was thus being continually refurbished at each attempt to write about it, with the result that what might even faintly look like an authentic Maori version of their past was buried beneath screeds of transcriptions and re-writes, filtered for supposed relevance and accuracy by the Victorian minds who committed them to paper.

The fate of the story of Maui serves as a conducive lesson in the potential for cultural corruption, regardless of how wellintentioned the efforts of either group may have been in sharing and reconstructing Maori knowledge of the past. For those early European ethnographers scribbling their way through the histories of Maori (told to them by an eclectic mix 
of native informants), the account of New Zealand being raised from the sea was a common story. This is not to say, though, that the versions were identical among all Maori communities. However, the nineteenth-century European craze for collecting cultural artefacts - in this case, oral histories - went hand-inhand with the similar enthusiasm of the age for what was seen as bringing civilised academic uniformity to primitive disorder. ${ }^{38}$ And to make matters worse, often, the most entertaining details from each variant of an oral history (entertaining, that is, to European audiences) were plucked like low-hanging fruit in order to produce more luscious narratives. The product of all this collecting, sorting, screening, editing, adjusting, and ornamentation of Maori oral histories was that by the start of the twentieth century, there was a small assortment of dense volumes competing for the public's and academics' recognition as being the implicitly definitive anthologies containing the 'standard' pre-history of Maori society - all of which had been distilled to their most immutable form, ${ }^{39}$ and many of which were marred by a host of 'scholarly sins'. 40 As a consequence, the role of the discovery narratives in Maori culture and society was altering swiftly and in some ways irrevocably during the period in which they were first being written down.

\section{Constructing Myths}

By the mid-nineteenth century, there were - broadly speaking - just two types of society in the world: those which had been born into European civilisation, and those which were having that civilisation thrust upon them. Maori society fell into the latter category, and one of the tell-tale signs of this was the transfiguration of its mythology from a profoundly sacred tableau at the nucleus of Maori identity, and a 'charter for traditional social institutions', ${ }^{41}$ to a specimen of interest to 
scholars, and from there, the final descent to a trivialised object of popular amusement.

The side-effects of this process were ruinous to parts of the indigenous culture. The basic ways in which such accounts were stored, transmitted, performed, and interpreted were all thrown into confusion by the emergence of a fixed written version of the myths. As a consequence, the means of acquiring and discussing certain aspects of cultural knowledge began to become separate from everyday community life, rather than being an integral part of it. Even traditional ways of thinking were altered to some extent: how Maori perceived and categorised their traditional knowledge, how they rationalised it in the context of the fast-changing colonial society they were a part of, and even perhaps how they valued it as something relevant to them (in the way it had been to their ancestors), began to shift away from the certainties that existed just a few generations earlier. ${ }^{42}$

By the twentieth century, a few of the more well-known Maori discovery myths, particularly that of Maui fishing up New Zealand, had been reduced (and degraded) in some instances to children's stories, in which only the literal narrative was laid out (often alongside whimsical illustrations) as a form of entertainment (obviously with all Maui's sexual exploits stripped away). ${ }^{43}$ This represents the reduction of oral culture and tradition to an absurd degree - to a collection of folksy fables which offer nothing more than a fictional diversion for their readers. And any regional variants of the Maui myth were lost as the story was condensed into a single uniform narrative. ${ }^{44}$ Anomalies in detail were an unnecessary distraction, it was thought, and reflected badly on the ability of the indigenous peoples of the Pacific to maintain the consistency of their founding stories. Any localised variants were 'tidied up' on the basis that they suggested laxity to European transcribers, even if such differences in the detail were, on the contrary, significant cultural points to the communities concerned. As it turned out in the case of many 
Maori myths and legends, a desire for standardised stories that suited the curiosity of European readers trumped any regard for other possible purposes and values these accounts might have had. After all, they were just 'primitive' creation stories, and so surely would not suffer in any way form these 'improvements'.

Yet, when examined closely, the Polynesian myths about the South Pacific's geography and its discovery have the potential to illuminate much of the early human activity of the region. At their core are actual rather than imaginary histories, although these are usually rendered more obscure by the thick film of metaphor which has been drawn over them. However, getting to the historical essence of these myths and legends is not as simple as just peeling off the metaphors and holding up whatever remains for examination. The spiritual realm from which these accounts and their characters were believed to have originated was understood by Maori to be beyond the ability of humans to comprehend fully. 45 Consequently, the Maori accounts of the formation and discovery of New Zealand - while containing both figurative and literal elements - can be perceived as adaptations of supernatural knowledge made to fit the limitations of human understanding, perhaps just as much as merely metaphor-laden explanations of creation. ${ }^{46}$ In addition, many of the gods in Maori mythology tended to be projections of the temporal aspects of the society that they presided over, doing the things humans do (cultivating kumara, going fishing, felling trees), all of which tied in with the agricultural basis of Maori communities. ${ }^{47}$

On yet another level, the discovery and creation myths reflect, to varying degrees, the sort of universal patterns of thought that existed in pre-industrial societies. ${ }^{48}$ They answered the question of how a landmass came into existence in an age and in a place where no more scientific explanation was available, and they offered a comprehensive narrative of discovery, even if all the details of who arrived where at what 
time did not always survive the strains that affect any elongated oral history. It is the absence of modern scientific knowledge about the natural world that made the minds of the ancient Polynesians fill the void with supernatural accounts of creation and discovery, onto which fragments of known and concocted history were appended. The detail of each story might vary, but the underlying themes were very similar.

The view that there is any historical currency at all in the discovery stories, though, has periodically aroused the chagrin of some academics. For the anthropologist Ralph Piddington, who considered this matter in the mid-1950s, the Maori tradition of New Zealand's discovery was enervated to 'a mechanism of validation for social, economic and sentimental claims'. ${ }^{49}$ The belief in the non-historical essence of Maori discovery stories was then taken up by David Simmons two decades later. Simmons suggested that the legends had more of a psychological basis, existing 'to justify claims to mana and land'.50 The vagaries of fundamental aspects of the traditional Maori accounts of New Zealand's discovery, together with contradictions in some of their peripheral details, did not help the cause of their proponents, and made arguing the case that these legends and myths contained at least a kernel of historical fact that much more strenuous.

If there was even some faint semblance of veracity in any aspects of the accounts of Hawaiki (the mythical Maori homeland), for example, the generally-agreed view during this period was that it lay 'buried under the accretions of time'. ${ }^{51}$ What put the original location of Hawaiki permanently out of the reach of historians was that the name itself had assumed a generic quality in Maori mythology, referring to whatever homeland a group of migrants departed from. Each time a voyaging canoe departed for its next destination, it left a Hawaiki in its wake. And when this settlement became the point of departure for the next group of migrants, it then 
assumed the name of Hawaiki. No doubt, legends and myths associated with each manifestation of Hawaiki were fused with its next incarnation. ${ }^{52}$ Disentangling the separate elements (chronologically or geographically) from such a great distance in time is now impossible given the nature and content of the corpus of myths and legends that have survived from that era. Hawaiki became an 'ever-shifting' concept rather than a fixed geographical location. 53

Given such fickleness, it was to be entirely expected that, increasingly, scholarship seemed to be putting the Maori histories of New Zealand's creation and discovery on a trajectory of fantasy. So when, in the 1980s, another anthropologist, Margaret Orbell, began sorting through these myths and legends, it came as no surprise when she concluded that their sole purpose had been to 'make the world meaningful' for Maori.54 The traditional histories of the discovery and migratory voyages were new perceived as journeys 'made in the mind, not at sea', 55 and that had been fabricated to fulfil political, sociological and religious purposes. How, after all, could the story of ancestors travelling thousands of kilometres across the Pacific Ocean on coconut shells, whales, turtles, or a giant octopus 56 be taken at all seriously? Yet, at least one nineteenth-century scholar had been prepared to concede that there was more to these narratives than met the eye: 'Accounts of the mythologies of the primitive tribes generally afford senseless caricatures', he wrote, 'so long as we are not acquainted with the religious notions around which they play. The knowledge of these beliefs is not easily gained, for the priests hide their doctrines under symbols which only the initiated can understand'. ${ }^{57}$ This symbolism was enormously important to the way in which Maori interpreted the supernatural world. It pointed people towards the direction of a type of experience that was much more mysterious and profound that that of their everyday lives, unveiling both the 'miraculous, inexplicable side of life' as well as the sacramental dimensions of human 
existence. ${ }^{58}$ The challenge lay in people being able to attune themselves to that mysterious and profound cultural realm which was the necessary starting point for understanding these myths.

By the second half of the twentieth century, academics (with a few exceptions) 59 were becoming more and more assured about how these creation and discovery stories fitted in to Maori culture, and how they were not always reliable even as loose emblems of history.60 Orbell's logic on this matter was straightforward: there were clearly mythical elements to the Hawaiki story (such as travelling on rainbows, albatrosses, and floating on pumice), and Hawaiki itself was not a single, identifiable location. On these bases, the Hawaiki story as a whole (including the migration sequences) were unreliable, and not worthy of consideration as any sort of history at all.61 Most other scholars with an interest in this area concurred, so when they sought to extract meanings from the myth, they did so with the tools of literary criticism, sociological exploration, or even psychological analysis. ${ }^{62}$ The prospect of any substantial historical material contained in Polynesian myths was deemed to be highly improbable, and to think otherwise would be to imbue the ancient cultures of the Pacific with a sophistication in oral history which they clearly could not have possessed. Even the fundamental basis of Polynesian voyaging was queried. 'What colonizing populations thought they were doing', asserted one academic, 'and what they were actually doing are two separate questions'.63 The most logical inference drawn from such statements was that the notion of accidental discovery of new lands by Polynesians applied to their motive as well as their method.

The trouble was that this increasingly confident refinement of a scholarly argument was occurring just as an alternative approach was coming into view - one that was giving some credence to the history contained in the discovery legends. ${ }^{64}$ In part, it had been the failure of earlier ethnographers (and 
those academics who followed in their wake) to acknowledge that this type of history was nourished by a cultural tradition that needed to be understood before it could be dissected. And as scientific research started to vindicate some elements of the Polynesian oral traditions, myths were beginning to 'illuminate ancient migration history' - lending credence to the suggestion that there were factual events at the heart of many of these stories. 65

At first glance, it looked like a potential impasse has been reached. Yet, both camps were nudging (sometimes hesitantly) toward a convergence of these approaches to understanding the Polynesian past. The realisation was dawning that the failure of either side to look over each other's fence and see things from an alternative viewpoint was 'debilitating', as Marshall Sahlins put it when making his plea for an end to the polarisation of intellectual thought in such areas. 66

But the historical inheritance can be a funny thing. Millennia of oral accounts from throughout Polynesia relating to the creation of the world and its islands (scarcely any of these myths dwelt on the possibility of continents) were too easily contaminated by outside influences. Especially in the nineteenth century, either through thoughtless transcriptions or more thought-out manipulations, the historical value and spiritual significance of these ancient myths was subsumed by the foreign culture that took it upon itself to interpret these stories and reproduce them in a more familiar and palatable form.

Even if the transcriber tried to remain as faithful as possible to what he was hearing, the act of jotting down anything that was part of an oral culture unavoidably excluded the nuances which accompanied these spoken narratives. This was particularly so when the transcriber came from an outside culture, and was not privy to certain specific non-spoken cues, as one Hawaiian who had been brought up in an oral tradition noted: 
A listener know what the speaker meant by perhaps the rise of an eyebrow, an expression of the face, a tilt of the head, or a description moulded with fingers. It has often been said, 'Tie a kanaka's hands and you will have him tongue-tied'. Many words had double, triple, and quadruple meanings, some not even remotely connected with each other. The same word pronounced one way meant one thing, yet pronounced differently it meant something else. The purport of a word depended not only upon inflection but also upon the words with which it was accompanied in a sentence. ${ }^{67}$

Partly because of these idiomatic challenges being strewn in front of even the most determined collector of oral histories, most of those who transcribed the histories they were told tended (usually unwittingly) to end up producing a highly Europeanised version of these narratives.

At this time, though, a few New Zealand ethnologists went even further. They took hostage the body of Polynesian creation myths and attempted to reconcile these stories with those of other cultures, dragging their readers though convoluted lines of logic and obscure and meandering histories in order to arrive at their illusive findings. Arthur Thomson's 1859 analysis of Maori origin myths came to a typical midcentury conclusion about their semblance with Biblical accounts of the world's origins: 'In the mythology of the New Zealanders classical readers may trace chaos; biblicists many texts in Genesis; and geologists forces which have given the earth its present formation. There are many who see in the fishing up of the land from the sea by Maui a type of the flood, detect a resemblance between the names of Noah and Maui, and a similarity between many Scriptural and Maori customs. In the transmigration of souls to certain animals, in the wooden images of the New Zealanders and in some of the attributes of the gods, a faint indication is given, which becomes more clear when connected with other things, that the New Zealand race have had intercourse with men holding the Hindoo faith'.68 Enthusiasm for the view that the Polynesian myths were not unique and instead belonged to a 
global myth-motif peaked in the early twentieth century, when some anthropologists glanced an opportunity for reducing all creation myths to a common template that had simply altered its shape as these stories migrated around the ancient world.

Such tenuous arguments, teetering on the weakest of intellectual footings, were driven by their authors' tireless desire to repatriate all of the world's pre-histories to a single home. Any of the more diverse elements of these traditions were left hanging like frayed threads, while their common strands were knotted tightly together, giving strength to the thesis that all the earth's peoples and cultures shared a common and conveniently Christian core.

Whether this approach to Polynesian histories was motivated more by the novelty of the argument, or the unvoiced apprehension that Christianity seemed to be losing its former authority in an increasingly secular and doubting age is uncertain. So manifestly contrived was this proposition, though, that it soon ran out of advocates who were feckless enough to keep pursuing it. However, by the time that these efforts at unifying Polynesian creation myths with those of other cultures had run their course, enough of the residue of this approach remained that, in some instances, Polynesians themselves were unsure where their authentic tradition ended and where these introduced aberrations began. If ever there was a case of exhibiting the fragility and vulnerability of oral cultures, the grafting of European ideas onto the limbs of traditional Polynesian creation myths was it. And as with all efforts at grafting, over time, the joins become harder to detect, and separating the indigenous from the alien becomes that much more difficult.

Some Pacific communities seemed to have absorbed outside histories with little apparent resistance and made them their own. It was at the heart of oral cultures that stories told by authoritative figures were taken to be true, and were added to the pool of existing accounts of the past. The purity of these histories was maintained as long as the self-contained 
island communities which nursed them remained isolated from outside influences. But once Europeans started to set foot in these communities, alternative histories were easily propagated and subsequently became a naturalised part of the culture. By the twentieth century, for example, the Kwara'ae people of Malaita in the Solomon Islands had an origin myth that traced their ancestors back to the wandering tribes of Israelites, 69 a Marquesan chant made reference to Queen Victoria being a descendent of the cultural figure Piko,70 a Hawaiian legend had incorporated the Noah and the Great Flood into its narrative, ${ }^{71}$ while in the 1920s, Henry Stowell (who sometimes wrote under the name Hare Hongi) made the observation to his readers that the Maori legend of Tawhaki (known elsewhere in Polynesia as Tafaki, Tafa'i, or Kaha'i) contained thirty parallels with aspects of Christ's life. ${ }^{72}$

Then there is the Maori myth of a great flood - an episode which was known as Parawhenuamea - which became personified (or more precisely, deified) under the same name. ${ }^{73}$ According to a latter nineteenth-century re-telling of this story, as the inhabitants of New Zealand multiplied in number and split into various tribes, they forgot to worship Tane - one of the founding gods. As a consequence of this neglect, evil began to dominate the country. Parawhenuamea, together with his father, endeavoured to keep their faith, but were derided for doing so by the rest of the populace. So out of desperation, Parawhenuamea made a raft from totara and kahikatea, and then prayed to Tane for rain as a way of convincing people of the god's power. The rains came, the sealevels rose, and those on the raft were saved. The rest of the people in the country - those who had mocked and cursed Tane - drowned in the deluge. Eventually, the flood subsided, the occupants of the raft gave thanks to their god for saving them, and set about repopulating the country. ${ }^{74}$

If this story sounds familiar, it should. Substitute Noah for Parawhenuamea, and God for Tane, and the resemblance to the account of the great flood in the book of Genesis is very 
close $^{75}$ - suspiciously so. ${ }^{76}$ The missionary influence on Maori tradition in this case is unmistakable, as Peter Buck conceded in 1950.77 There is potentially more to this mimicry, though, than an effort at cultural ingratiation, or some attempt to fortify creation and discovery narratives by adding imported materials to them (although neither of these motives can be excluded). The synthesis of traditional Maori mythology with Christian accounts of creation simultaneously was an act of assimilation and rebellion.

The assimilation is obvious in the convergence of the Maori flood story with the one introduced by the missionaries. However, a strong reactionary seam lies side-by-side with it. Firstly, the Parawhenuamea myth, in its nineteenth-century form, was a warning for Maori to retain their traditional beliefs in the face of an onslaught by a new religion. The missionaries who freely denounced the pantheon of Maori gods were the equivalent of those critics of Tane who were killed in the great flood. Maori audiences who heard this myth were also reminded of the power of tohunga - a group who were similarly under threat by the introduction of Christianity. If pushed too far, tohunga could bring about the destruction of the infidels. The underlying message of the revised Parawhenuamea myth was that the wrath of the traditional gods could return if Maori strayed too far from their allegiance to them. ${ }^{78}$

And for those inclined to look for even deeper symbolism in such hybrid myths, the Parawhenuamea flood story can be interpreted as a prophetic account, in which those who hold fast to their ancient traditions will be afforded the opportunity to escape from the cultural corruption of colonial New Zealand. ${ }^{79}$ A much stronger symbolic motif in the Maori flood myth, though, is that of re-birth. Of course, this, too, has a strong Christian resonance, but in the context of the Parawhenuamea story, the chance to be re-created (effectively, to be saved) was on offer strictly in the setting of revived traditionalism. This, again, was a counter to the spiritual 
opportunities being offered by the colonial culture in the nineteenth century.

A different sort of tension was also evident in the Parawhenuamea myth, but this one concerned Europeans. It rested on the debate over whether it was better to aid the work of evangelists in New Zealand by aligning Maori and Biblical histories - thus encouraging Maori to view Christianity (initially) as little more than an improved version of their own religion - or, as the more determined proselytisers had preached from the early nineteenth century, to accentuate the evils of indigenous mythology, thereby presenting Christianity as a trenchant alternative rather than an adaptable surrogate. In the end, it was the views of people such as the Wesleyan missionary Nathaniel Turner, who saw traditional Maori society as the source of 'every heathen abomination', 80 which won out, and the occasional blatant attempt to re-create Maori mythology in the image of Christianity failed to attract much support.

Admittedly, few myth fusions were as overt as the Parawhenuamea flood story. The pollination of Maori histories with European elements generally tended to be more subtle and inconsequential, and at least as much the product of a cross-cultural misconstrual rather than deliberate corruption. But regardless, to some extent, the appearance of European elements or perspectives in the corpus of Maori mythology inevitably sullied the purity of some of these narratives.

If the introduced account of the Flood story insinuated itself into Maori mythology to such an extent, could the accompanying theological elements associated with the Biblical narrative of the Flood also have trickled in? The possibility assumes some importance because of the specific relationship between humanity and the natural world that is revealed in Genesis in the wake of the Flood.

According to the Genesis account, after the waters had receded, God blessed Noah and his sons and instructed them to multiply and populate the earth (just as Tane had 
counselled the survivors of the Maori flood). In the Biblical version of the story, though God gave humans dominion over all living things: 'The fear and dread of you will fall on all the beasts of the earth, and on all the birds in the sky, on every creature that moves along the ground, and on all the fish in the sea; they are given into your hands. Everything that lives and moves about will be food for you. Just as I gave you the green plants, I now give you everything'. ${ }^{81}$

The Creator also promised that He would never flood the world again. Humanity's sins since the Fall had been absolved, and even though evil would remain, humanity was left with an ordered universe in which God guaranteed regularity, structure, and permanence in nature. ${ }^{82}$ Mankind's position at the centre of the cosmos was thus confirmed by divine covenant - a comforting assurance whenever people's thoughts strayed to considering the fragile and temporary nature of their existence and their inconsequential scale in an infinite universe. Dominion over all of nature and acting as the guardian of God's Creation was generous compensation. Even though how nature worked remained a mystery something God had not fully revealed - humans were nonethe-less central in the divine order of the natural world. 83

Cataclysmic floods had served another purpose in Europe's understanding of the non-European world: they helped explain the different stages in the development of peoples from the 'New World' - something that Francis Bacon speculated on in his lavish account of the discovery of the 'New Atlantis' in the 1620s: ${ }^{84}$

The Great Atlantis was utterly lost and destroyed; not by a great earthquake...but by a particular deluge, or inundation; those countries having at this day far greater rivers, and far higher mountains to pour down waters, than any part of the old world. But it is true that the same inundation was not deep, nor past forty foot, in most places, from the ground, so that although it destroyed man and beast generally, yet some few wild inhabitants of the wood escaped. Birds also were saved by flying to the high trees and woods. For as for men, 


\begin{abstract}
although they had buildings in many places higher than the depth of the water, yet that inundation, though it were shallow, had a long continuance, whereby they of the vale that were not drowned perished for want of food, and other things necessary. So as marvel you not at the thin population of America, nor at the rudeness and ignorance of the people; for you must account your inhabitants of America as a young people, younger a thousand years at the least than the rest of the world, for that there was so much time between the universal flood and their particular inundation. For the poor remnant of human seed which remained in their mountains, peopled the country again slowly, by little and little, and being simple and a savage people (not like Noah and his sons, which was the chief family of the earth), they were not able to leave letters, arts, and civility to their posterity. ${ }^{85}$
\end{abstract}

Such fantasising as was not the preserve of over-zealous Enlightenment philosophers or Victorian scholars, though. Even as late as 1930, a superficially plausible attempt was made by the anthropologist Nora Chadwick to reconstruct Polynesian history to suit European scholarship. In this case, a firm link was laboriously drawn between a Polynesian and a Japanese migration narrative. Chadwick excitedly discovered similarity after similarity between the story of Kae - which was widespread in the South Pacific - and the Japanese account of the deity Ho-Wori no Mikoto. The resemblance was so close that she concluded they must have been 'derived from a common source'. Her observation that 'the brilliant and enlightened Japanese court of Nara was in touch with the outside world in the eight century', and that this was also the period 'to which all historians agree in placing the beginning of the period of Polynesian maritime enterprise and traditional legendary history' seemed to clinch the argument. All other possibilities were swept aside in the quest for this common trunk that fed Japanese and Polynesian branches of migratory myths. ${ }^{86}$

Yet, even with such scholarly imperfections - imposed or accidental - it is still possible to disentangle some of the threads of traditional Maori exploration and discovery stories, 
and separate them from the more obvious European strands that were entwined around them from the nineteenth century. One way to begin fathoming the Maori accounts of the discovery of New Zealand is to acknowledge that the stories are rich in allegorical elements. This characteristic invited the listener (this was an exclusively oral culture) to deduce some meaning from every morsel of detail that was told to them, and in the modern era, enables some broad conclusions to be drawn about certain aspects of Polynesian migrations.

To start off with, there are numerous accounts in these myths and legends of people travelling between islands - many to neighbouring atolls but some to more remote locations. ${ }^{87}$ In addition, there were many more stories about the earliest settlers 'who groped their way into Polynesia from the hither end of the Micronesian route', but whose details, Buck lamented, 'have been effaced by the fingers of time, and such fragments as may have survived have been converted into myth or plagiarized by the historians of a later school'.88

In the repetition of these inter-island journeys, Polynesian mariners attuned all their senses to the various currents, swells, tonal shades, and waves of the ocean, ${ }^{89}$ and connected these in their minds with the position of the sun, moon, stars, and even clouds, to construct an entire body of navigational knowledge. When combined, these many narratives portray an image of canoe journeys that were essentially reconnaissance voyages, and that as canoe technology and sailor confidence grew, so too did the span of their exploratory steps increase.

Sifting through the myths and legends of Polynesian migrations, it would be easy to see the succession of islandhopping over many centuries having occurred in spite of the obstacles of the elements - that sailing from one atoll to the next was undertaken with a determination that overrode whatever the oceans and the weather could throw at these intrepid mariners. That was indeed largely the case, but there was a period when the climate obliged, lending a small helping 
hand by offering ocean-traversing migrants generally clearer skies, more favourable winds, and reduced storminess. 90

So in addition to increasing population pressures, warfare, accidental voyaging, and an habitual desire to move to new locations, ${ }^{91}$ the convergence of favourable climatic and oceanic conditions meant that for the roughly thousand-year period between 350 and $1350 \mathrm{AD}$, the chances of a successful longdistance migration across the Pacific improved from what they had been in previous centuries. In itself, this was not what drove Polynesian communities to traverse thousands of kilometres of the Pacific Ocean, but it did mitigate the frequency of weather and meteorological extremes that otherwise would have defeated some of the migratory ventures.

So these were some of the temporal aspects that constituted the elementary ingredients of Polynesian exploration. But there was an accompanying aspect to this nautical probing that was equally as important: the sacred encounter of people with the ocean, which made the seas the accomplice of Polynesian migration. ${ }^{92}$ However, the emergence of these types of ideas about people's relationships with the natural world could not have developed without societies first having a feeling for and an interpretation of nature. 93

The ocean was considered by Maori to be a god, with Ranginui, the deity representing the sky, having at one stage eloped with both Papatuanuku, the 'Earth Mother', and then Wainuiatea, the 'Great Open Space of Waters'. 94 The offspring of this latter union was a series of divinities, which included Moana-nui (the great ocean), Moana-roa (the extensive ocean), Moana-potango (the gloomy ocean). ${ }^{95}$ The understanding of the ocean had developed from being just a large body of water to a powerful supernatural being, or indeed, several deities. 96

It was no wonder the ocean continued to be popularly regarded as a deity - it was the fulfilment of all the imaginative musings about eternity. The sea had no frontiers, was an inexhaustible source of food and the origin of the weather, and barring the rare occurrence of a volcanic eruption or an 
earthquake, was the most powerful and terrible force people encountered. And it was not just its scale that made it so daunting. As Edmund Burke observed in 1757, 'A level plain of a vast extent on land, is certainly no mean idea; the prospect of such a plain may be as extensive as a prospect of the ocean; but can it ever fill the mind with any thing so great as the ocean itself?' The answer was no, and the main reason given by Burke was that the ocean was the object of terror. 97 Even the repetitive rhythms of the waves contributed to the aura of the ocean's chilling endlessness. The relentless lapping of the sea on the hulls of the migratory canoes - that 'long, deep, and monotonous swell',98 as Mulgan put it impressed on the imaginations of their crews the sense that the ocean had no limits. ${ }^{99}$

The ocean was also the place where the souls of the dead traversed. For Samoans, the spirits of the departed 'dived into the sea on their way to the spirit land'; in Rarotonga, the spirits similarly travelled beneath the ocean en route to Avaiki - the final destination of these souls; and it was the same for the Hawaiians, the residents of the Chatham Islands, the Fijians, and most of the other cultures of the South Pacific. 100 However, the ocean was more than just an abstraction, a state of mind,101 or a representation of infinity where people deposited their fears. It was a living entity, capable of pounding violence or docile placidity. It heaved with swells, was riven with currents, and encircled the small protrusions of coral or scoria on which these island populations lived.

Yet, for everything that was threatening about the prospect of sailing out into the ocean, there was something enticing about this entrance into infinity. The German Idealist Johann Fichte realised this power in the notion of endlessness, and described how 'The idea of an infinity...floats as a vision before us, and is rooted in our innermost nature. We are obliged to resolve the contradiction [of realising the infinite]; though we cannot even think it possible of solution and foresee that in no moment of an existence prolonged to all eternity will we ever 
be able to consider it possible.' ${ }^{102}$ He then reflected on the nature of people who contemplated infinity and endeavoured to engage with it. For Fichte, such contemplation was evidence that they were 'destined for eternity'103 - to conceive of infinity as inconceivable was ultimately to become a part of it.

Hegel believed that those who ruminated on infinity, (a concept he interpreted as 'the pure nullification of...finitude') would discover 'the spring of eternal movement'. 'Out of this nothing and pure night of infinity', he suggested, 'as out of the secret abyss that is its birthplace, the truth lifts itself upward'.104 And even if the truth did not quite manage to rise to a sufficient height, infinity was still its source. The key needed to enter the realm of the infinite, according to the nineteenth century German philosopher Friedrich Schelling, was the imagination, which he cast as a way of thinking that 'oscillates between infinity and finitude'. ${ }^{105}$ The use of the imagination was the link that bound the here-and-now to various views of eternity.

Given these complex and sometimes competing religious and philosophical concepts associated with ocean-bound exploration, it is not surprisingly, then, the relationship Polynesians had with the sea was an ambivalent one - a mixture of comprehension and apprehension, repulsion and attraction. ${ }^{106}$ 'To be at sea', concluded Colin Richards in his penetrating study of Polynesian voyaging, 'was to experience the world in an alternative manner'. ${ }^{107}$ So in order to travel across this watery god, Polynesian sea-farers had to rely on intercession with other deities - often those ones sequined in the celestial realm. Navigation by stars, the sun, the moon, and elements 108 was all part of the 'transcendental'109 metaphysical scheme of travelling from one island to another, and was as much if not more a sacred rite than a scientific discipline.

In his monumental work on historical geography, Traces on the Rhodian Shore, Clarence Glacken argued that it would 
be difficult to exaggerate the importance of astrology in the history of human thought, but that it would be equally hard to appreciate its full significance. ${ }^{110}$ The stars certainly illuminated Polynesian mythology, but also served a deeper purpose as one of the fundamental 'scientific' principles of natural law in the pre-Newtonian world:

The stars were not themselves affected by their movement and light, since they were eternal and incorruptible. But their motion and rays had to have some effect, and an outlet for this vast store of energy was found in our elemental world, whose changes and fluctuations and variations paralleled the shifting patterns of the eternal heavens and the varying projections of the rays of light....the earth was thought of as the center and bottom of the universe, and it was fitting that inferiors should be ruled and governed by superiors - the heavenly bodies. ${ }^{111}$

Theology, astronomy, astrology, meteorology, and geography overlapped in such cultures to the point where there were merely branches of the same generic discipline. ${ }^{112}$ For Polynesians, there was a harmony in the natural world they experienced that was lost on most later Western onlookers. ${ }^{113}$

The consequent loss in the traditional sense of the mythic vitality of the natural world was something that even in the mid-nineteenth century, a few observers were already beginning to acknowledge and even regret. One of these was the classical historian George Grote, who in 1846 wrote that 'the physical world as it is now studied and understood...[is] a lifeless and impersonal aggregate, slavishly obedient to the rules of which it has no consciousness, and destitute of all sympathy with the men who suffer or profit by it'.114 Science was already stripping away the magic which some cultures believed governed the natural world, and as the pool of myth which put this supernatural world in human terms gradually dried up, even some of those who were responsible for the relentless march of Western academic disciplines occasionally 
had cause to stop and lament what they were destroying in the process.

For the ancient Polynesians, the very act of traversing the sea in a waka was considered primarily a supernatural undertaking by those involved, and had become emblematic of humanity engaging with the divine. ${ }^{115}$ Precisely how this encounter with the spiritual world unfolded for the crews of exploratory and migratory waka hinged on the abilities of one passenger in particular: the tohunga. It was he who was responsible for beseeching and placating the gods, he who assessed the changes in the elements, and he who jealously guarded the mystery of how navigation worked. A chant that Buck transcribed is typical of the type of invocation that was uttered at the commencement of a voyage, showing how great the faith in the supernatural was in ocean voyaging:

\footnotetext{
Now do I direct the bow of my canoe

To the opening whence arises the sun god,

Tama-nui-te-ra, Great-son-of-the-sun.

Let me not deviate from the course

But sail direct to the land, the Homeland.

Blow, blow, O Tawhiri-matea, God of the Winds!

Arouse thy westerly wind to waft us direct

By the sea road to the Homeland, to Hawaiki.

Close, close thine eye that looks to the south,

That thy southerly wind may sleep.

Allow us to sail o'er the Sea of Maui,

And impede us not on our course. ${ }^{116}$
}

In ancient Polynesia, notions of spiritual and temporal were still separate, but existed like two sides of the same coin, rather than as concepts in competition with each other. Interaction with the sea was one of the junctions between the two realms. ${ }^{117}$ In their hardy canoes, Polynesian explorers braided out over these waters, guided by visible elements, but also by myths. According to the mythology of most Polynesian cultures, there would always be a kaitiaki - a guardian - to assist if the voyage got into trouble. The kaitiaki might 
materialise in the form of a turtle, an octopus, or some supernatural apparition, and would then disappear once they had helped the sailors. ${ }^{118}$

Faith in kaitiaki, and faith in the notion of another land existing in the abyss of the ocean, was enough to overcome the obvious and deep terror of embarking on these seemingly doomed voyages of exploration. For the sailors on these vessels, all the certainties of life on their small islands diminished with each breaking wave they paddled through, until the sound of the putona - the trumpet shell - could no longer be heard from the shore, and the pointed tips of their islands - punctuating the vast seascape - disappeared below the horizon. They were now all alone in the brooding ocean, sailing always towards that point where the sea and the sky 'were welded together without a joint' as Conrad visualised it. 119

If the ocean was viewed by ancient Polynesians as a deity, it was certainly not as some static, ivy-entwined idol, lodged in the jungle in front of which easy rites of reverence could be performed at one's leisure, or as a distant, primordial demigod whose name was recited by a tohunga in some obscure ancient chant. Rather, it was a living thing - 'moody and unpredictable', 120 visible, animated, volatile, not carved from wood or rock as other gods were, but constantly writhing, like some massive, unsettled, primordial entity. In religious rituals, its waters were a physical and spiritual cleanser, and a symbol for purity. ${ }^{121}$ To the imagination of people at that time, the ocean was depthless, furious, and yet presented itself to mortals as something to be challenged and probed. This made exploratory journeys acts of faith in both their abilities to venture into the unknown, and in the ocean to deliver them to their destination or to consume them en route. Polynesians were conditioned to see the ocean as sacred, and interpreted their encounters with it in that context. ${ }^{122}$

It is little wonder, then, that the myths that emerged from these voyages, and that were carved into the memories of 
successive generations of Maori, represented an absolute truth about their origins. ${ }^{123}$ After all, a prolonged communion with the divine - which in one way is what the process of migration across the ocean was - lay at the very core of all subsequent religiosity for the communities formed as a consequence of these migrations. In the same way that land-raising made the sea an agent in Creation, the act of migration (inadvertently) made the sea an agent not just in social transformation ${ }^{124}$ but of social genesis. Voyaging was the time when the sacred first appeared, and when the structure of the Maori world was established. Mircea Eliade argues that all myths are, in that sense, origin myths: 'myth, then, is always an account of a creation'.125 Like many traditional societies Maori believed that the power of a thing lay in its origin. ${ }^{126}$ The abiding rule seems to have been that 'it is the first manifestation of a thing that is significant and valid'. ${ }^{127}$ So one eye of Maori culture was permanently trained on the past, recalling those first appearances - of land, of the creation of plants and animals, or demigods, and so forth - that fortified myths and that gave them such lasting prominence in Maori society. The other eye, however, saw these myths as histories of the present. They were not punctuation points in a linear history, but were part of a cyclical view of the world, in which the themes and ideas in the creation and discovery narratives had current applications. Taken one stage further, the ancestors' appeared in the living as history emerged and was actualised'.128 The past and the present were thus compressed into a single concept.

\section{Perceptual Issues}

In the nineteenth century (and often in more circumspect ways in the following one) various European writers were inclined to treat the ancient Polynesians as sociological specimens, represented by the archaeological traces that survived them, 
patterns of linguistic similarities, and a corpus of mythology that sometimes bore a connection to the evidence, but more often appeared not to. The lesson for anthropologists that was to be found in the roles of religious beliefs and science in traditional Polynesian communities was sometimes slow to be learned.

Science existed for the ancient Polynesians, but much more as a revelation of the supernatural realm than as an alternative to it. Myths remained the cultural location where material knowledge about the world was deposited. Whenever this knowledge was required, it first had to be uncoiled from this sacred setting (there was nothing of the straightened-out European methods of recording and disseminating information). Admittedly, there were the ubiquitous tributes paid to the gods and demi-gods that a cynic might interpret as the sort of obligatory declarations that prefaced the more temporal aspects of how nature worked. Certainly, most Polynesian creation myths, for example, had their tellers focussing on how things came into being, rather than on any more abstract notions of Being and Non-being. ${ }^{129}$ However, mythology, and the scientific knowledge lodged within it, remained at the core of ancient Polynesian societies. No matter how advanced techniques in waka construction or navigation became, myths were never relegated to the periphery of traditional Pacific communities. Unlike the strides towards secularism in the West that gathered pace with each scientific advance, Polynesians seem not to have suffered from the myopia that knowledge about how things work was best expanded in the absence of any sense of the mythical proportions of the universe. When it came to the means of navigating their way to new lands, for example, it was received wisdom for Polynesians that the gods assisted them, guided them across the great ocean, watched over them as they rode out the ocean gale to the stone sea anchor, protected them from all the dangers of the deep....Kahu-kura, the rainbow god, acted as pilot...Hine-korako (lunar halo 
personified) guided them...Ruamano, the sea monster, led the way'. ${ }^{130}$ The sacred was thus much more than just a staid ritual stuck in a rut of tradition.

In a way, the Polynesian approach to knowlwdge combining myth and scientific erudition - made everything in the world explicable. There was no need to peek behind the curtain to try to discover how things worked. The answer was that the gods made them work, so what else was there to know? Whatever social and technological developments did occur took place in increments so small and gradual that they were practically indiscernible over a lifetime. The sort of technology used by one generation would in most cases be almost identical to that used by its children and their children.

Of course, it was easy for nineteenth-century European writers to scoff at the ancient Polynesians. After all, these primitive peoples were apparently beckoned to traverse the vast Pacific Ocean - probably more often than not in voyages that doomed their crews to a watery internment - by mythical deities, and lacked even the means to record reliably their feats, let alone undertake them with anything resembling scientific certainty. When undertaking a brief survey of New Zealand's mineral constitution in 1859, the geologist Ferdinand von Hochstetter paused to record his personal assessment of the mythology that was central to any Maori recounting of their arrival in the country. For the visiting German, the true origins of Maori were 'shrouded in profound obscurity', for which 'Mysterious legends and traditions seem to convey [only] vague historical reminiscences'. Any effort at sifting through the calcified remains of these ancient myths was a waste of time. 'We must not search for historical truth in those traditions', he cautioned his readers, 'as we thereby involve ourselves in a labyrinth of mythical fancies'. ${ }^{131}$ The mistake here was for von Hochstetter to get entangled in his own perception of the role that mythology and religious beliefs played in directing the decisions of the Polynesian explorers. He failed to see these myths as being inextricably linked with a 
much more primeval impulse shared by all peoples: the urge to explore to the utmost extent that the available technology allows. The determined act of sailing towards the horizon with no inkling of what lay beyond, and with faith vested in the supernatural, was not the sole preserve of the occupants of the archipelagos in the South Pacific. Curnow's 1942 homage to the discovery of New Zealand - Landfall in Unknown Seas revived in verse some of optimism and religiosity of those early Europeans explorers when similarly setting out on their expeditions into the uncharted distance:

you launched the whole

On a fine morning, the best time of year,

Skies widening and the oceanic furies

Subdued by summer illumination; time

To go and be gazed at going

On a fine morning, in the Name of God

Into the nameless waters of the world. ${ }^{132}$

That 'European colonisation' has become a pejorative term for most historians, though overly simplistic, is hardly surprising. The conflicts that were almost habitually unleashed by explorers and those who followed in their wake have become standard fare for historians - an obvious beginning for any account of colonial encounters. Only that these clashes were just as much the conclusion of one phase of encounter as they were the commencement of another. The long act of imagining a new location, which preceded every exploratory venture, was the meditative state from which those involved could only be awoken by the visceral reality of arrival. All the imaginative musings about discovering a new country were brought to a juddering halt when landing boats were hauled on shore.

But was conflict of any sort the inescapable conclusion of fanticising about other places? Is it some predisposition of the human condition for those initial moments of encounter to twitch like exposed nerves, and sometimes break out into 
violence? We would like to think not. It puts a blemish on the whole of Western Civilisation to suggest that its unrivalled cultural virtues could convulse into brutish vices when first coming face-to-face with any part of the non-European world. Yet, it happened with such regularity in so many territories that it has become part of the set-piece narrative of colonial histories. However, the fact of its wide dispersion and frequency does not help much in explaining why these moments of contact precipitated hostility almost as through a reflex action. Surely the Enlightenment had taught inquisitive Europeans to enquire about the unknown rather than to attack it? Fighting anything that was not understood was the response expected from Catholic Europe in the Dark Ages, not the intellectually illuminated Protestant Europe of the early modern era. But the problem of clashing on initial encounter lay much deeper than anything to do with advances in science or understanding. 133

In New Zealand's case, many of those who intended to explore the country in whatever way during the early nineteenth century would have started out by trying to lay their hands on any information they could find about the location. However, prior to the Treaty of Waitangi (1840) which ushered in formal British rule over New Zealand, sources of information were scarce and sometimes dubious in reliability.

When it came to New Zealand's terrain, the number of its inhabitants, and its natural resources, ${ }^{134}$ and so forth, often, rumour and expectation were all anyone had to go on. With such a lack of certainty, those who made it their goal to travel to New Zealand in this period were forced to fall back on their imagination to colour in the blank spaces left by the absence of sufficient hard facts on the nature of the country. From the outset, though, there were two types of imagination at work: one which predicted that the destination would be a harsh, sinful place; and the other, which anticipated a natural, uncomplicated, pristine location, offering redemption, not 
damnation, for the soul.135 Missionaries were voluminous producers of opinion in the former category, but the case for New Zealand as an Elysian apparition could be just as compellingly made. One such heavily-dabbed though not untypical vignette gives an ample impression of the extent to which the country could conform to the European notion of the 'ideal':

not only is vegetation highly luxuriant, whether of the trees or of the pastures, but perpetual, and the atmosphere so clear, that objects are visible at a great distance; and the varying, but ever beautiful, tints of the bright sky, and picturesque scenery are a constant source of admiration. Cattle and sheep never require to be housed, as there is no frost or excessive damps to injure them, and the pasturage lasts throughout the year. Fogs, excepting always the morning exhalations above mentioned, are almost unknown, excepting in the southern extremity of the islands, and even the southerly winds, springing as they do from the antarctic regions, are so tempered by the extent of water over which they pass, as to be totally free from the unpleasant qualities of our English easterly winds....The scenery, especially in the open glades of the forests in the warmer districts, is often extremely beautiful. The tall tree-ferns and large flowering forest trees, for many of the larger trees bear flowers in New Zealand, also add much to the beauty of the woods....[Much] may be said in praise of the extreme beauty of the scenery in some portions of New Zealand, where the natural undulations of the ground, the wild mountainous hills in the distance, and dense forests of magnificent timber, interspersed with numerous flowery creepers, running down to the water's edge, with foliage surpassing in richness of colour any of our native trees, all combine to increase the beauty of the landscape. ${ }^{136}$

Such extremities potentially set the stage for some form of fractious encounter. Faced with any reality that contradicted imaginative longings, the opportunity existed for elements of 'coercion, racial inequality, and intractable conflict' to surface. In some instances, the encountering cultures had no better way of reconciling these differences other than clashing. ${ }^{137}$ 
Animosity might have been the result, but it was seldom if ever the premeditated intent. As far as I have been able to see, there was not one person who intended to visit New Zealand in the early colonial era with the expressed aim of engaging in direct conflict with Maori. On the contrary, the act of researching a destination and imagining its cultural, physical and social dimensions, was meant to soften any possible confrontation. The more culturally porous the arriving European was prepared to be, the more his or her ultimate interests would be served. ${ }^{138}$

The voyages of Cook, in particular, had 'torn away the veil from an unknown half of the world', 139 and in his aftermath, ideas about New Zealand rose back in Europe like an ocean swell. Cook's deadpan description of the country dispelled for many of his readers any fantasies they may have had (simply from a vague knowledge of the country's existence) about an unspoilt Antipodean Eden. All the seductive propositions of Rousseau and his disciples about Noble Savages living in a bounteous rustic paradise crashed up against 'the decrepitude and political impotence' of contemporary Maori society. For some energetically-minded Europeans, this dissonance between how they felt New Zealand should be and what it turned out to be begged for a resolution. What emerged among them was a desire to 'rescue' Maori and elevate them to a state of 'grandeur'. ${ }^{140}$ For this group of would-be social redeemers, the supposed condition of the nation was the point of departure, from imagining New Zealand to 'doing something about it'. And the first stage in that mission involved travelling to the country.

Any such journey was bound to be an act of faith, but in the early nineteenth century, there was just enough knowledge about the world to invest this faith with a self-assuring application of scientific certainty. All that was needed now was 
some sort of organised effort for an expedition to this unclaimed antipodean location.

There is no doubt that the will to discover New Zealand for themselves was a compelling motivation for would-be settlers and entrepreneurs. This was a period when one could say, quite literally, that a world of opportunities lay around them waiting to be exploited. And when these people looked beyond the boundaries of the British Empire, their imaginations drifted to visions of a bucolic paradise - one perhaps endowed with fertile soils, a temperate climate, docile natives, and stout British yeoman deriving their prosperity directly from the land. If such an apparition could be realised, it could herald a return to the sort of rustic glory that nostalgics liked to believe Britain had once enjoyed. Maybe this ideal could be transposed to a territory as yet unscarred by heavy industrialisation and an impoverished agricultural workforce driven to crowded urban slums to seek employment. It could be a chance to redeem the best of British national character, and more importantly, it could also turn a nice profit if managed appropriately. The granules of this view of New Zealand washed around in the minds of a group of similarlyminded part-time entrepreneurs in the early 1820 s, and when - like sediment - they began to settle, a more distinct view of an investment possibility in New Zealand began to come into view. The more they considered prospects of life in the country, the more this destination glistened with altruistic and financial opportunities. 


\section{Notes}

1 Elements of this article are taken from my book Encounters, the Creation of New Zealand, A History, Auckland, 2013.

2 C. W. Hendel, Studies in the Philosophy of David Hume. Indianapolis 1963, p. 25.

3 D. Hume, L. A. Selby-Bigges (ed.), A Treatise of Human Nature, Oxford, 1896, p. 142.

4 Ibid., p. 88.

5 G. Streminger, 'Hume's Theory of Imagination', in Hume Studies, vol. VI, no. 2, November, 1980, p. 93.

6 Op. cit.

7 D. Hume, L. A. Selby-Bigges (ed.), A Treatise of Human Nature, p. 28.

8 J. A. Bates, Hegel's Theory of the Imagination, New York, 2004, p. 4.

$9 \quad$ P. Theroux, The Great Railway Bazaar, New York, 1977, p. 379.

10 R. D. Craig, Dictionary of Polynesian Mythology, Connecticut 1989, p. xi; also see P. V. Kirch, The Evolution of Polynesian Chiefdoms, Cambridge, 1984, p. 71 .

11 There is occasional mention of traditional Maori imagination in some literature, but is a topic that has only obliquely been examined. See G. H. Smith, 'Indigenous Struggle for the Transformation of Education and Schooling. Keynote Address to the Alaskan Federation of Natives (AFN) Convention', Anchorage, 2003, p. 2; R. S. Hill, 'Social Revolution on a Small Scale': Official Maori Committees of the 1950s', paper presented to the New Zealand Historical Association Conference, Wellington, 24-27 November, 2005, p. 3; H. Matunga, 'Urban Ecology, Tangata Whenua and the Colonial City', in G. H. Stewart and M. E. Ignatieva (eds.), Urban Biodiversity and Ecology as a Basis for Holistic Planning and Design: Proceedings of a Workshop held at Lincoln University, 28-29 October 2000', Christchurch, p. 68; E. Best, 'Polynesian Navigators: Their Exploration and Settlement of the Pacific', in Geographical Review, vol. 5, no. 3, March 1918, p. 172. Also see I. Arteljevic, 'Searching for Nature and Imagining New Zealand', in Journal of Travel and Tourism Marketing, vol. 10, no. 1, 2001, p. 115 .

12 M. Kahn, 'Tahiti: The Ripples of a Myth on the Shores of the Imagination', in History and Anthropology, vol. 14, no. 4, 2003, p. 307.

13 P. D. Nunn, 'Fished Up or Thrown Down: The Geography of Pacific Island Origin-Myths', in Annals of the Association of American Geographers, vol. 93, no. 2, June 2003, p. 351.

14 G. Benanrdo, 'Map Drawing in Tonga, Polynesia: Accessing Mental Representations of Space', in Field Methods, vol. 14, no. 4, 2002, pp. 392, 405. 
C. Richards, 'The Substance of Polynesian Voyaging', in Word Archaeology, vol. 40, no. 2, 2008, p. 217.

16 A. C. Haddon and J. Hornell, Canoes of Oceania, Honolulu, 1975 [1936-9].

17 C. Richards, 'The Substance of Polynesian Voyaging', p. 211.

18 G. J. Irwin, The Prehistoric Exploration and Colonisation of the Pacific, Cambridge, 1992, p. 44.

19 B. R. Finney, 'Myth, Experiment, and the Reinvention of Polynesian Voyaging', in American Anthropologist, vol. 93, no. 2, 1991, p. 397.

20 For discussions of dimensions and capacities, see R. C. Suggs, The Island Civilizations of Polynesia, p. 77; D. Lewis, We the Navigators: The Ancient Art of Landfinding in the Pacific, Honolulu, 1994, pp. 79-80; E. S. C. Handy, Marquesan Legends, Honolulu, 1930, p. 130; D. Malo, Hawaiian Antiquities, (N. B. Emerson, trans.), Honolulu, 1951, p. 168.

21 E. S. C. Handy, Marquesan Legends, Honolulu, 1930, p. 131.

22 C. Richards, 'The Substance of Polynesian Voyaging', p. 212; C. Richards, 'A Choreography of Construction: Monuments, Mobilisation, and Social Organisation in Neolithic Orkney', in J. Cherry, C. Scarre, and S. Shennan, Explaining Social Change: Studies in Honour of Colin Renfrew, Cambridge, 2004, p. 107.

23 R. W. Williamson, Religion and Social Organisation in Central Polynesia, Cambridge, 1937, p. 173.

24 J. Smith, in P. L. Barbour (ed.), The Complete Works of Captain John Smith (1580-1637), vol. 2, North Carolina, 1986, p. 338.

25 M. Beckwith, Hawaiian Mythology, New Haven, 1940, p. 230; L. Fison, Tales from Old Fiji, London, 1907, p. 144; C. Godsen and C. Pavlides, 'Are Islands Insular? Landscape vs. Seascape in the Case of the Arawe Islands, Papua New Guinea', in Archaeology of Oceania, vol. 29, 1994, p. 162; I. Barber, 'Sea, Land and Fish: Spatial Relationships and the Archaeology of South Island Maori Fishing', in World Archaeology, vol. 35, no. 3, 2003, p. 434.

26 S. Oppenheimer, Eden in the East, London, 1998, p. 237.

27 G. Turner, Nineteen years in Polynesia, London, 1861, cited in P. D. Nunn, 'On the Convergence of Myth and Reality: Examples from the Pacific Islands', in The Geographical Journal, vol. 167, no. 2, June 2001, p. 129.

28 E. Hadfield, Among the Natives of the Loyalty Group, London, 1920 , p. 225.

29 P. D. Nunn, 'On the Convergence of Myth and Reality: Examples from the Pacific Islands', p. 129. Nunn cited the following sources: G. T. Barker, 'How a Coral Reef Became an Island', in Transactions of the Fiji Society, 1926, pp. 29-34; E. W. Gifford, Tongan Myths and Tales, Honolulu, 1924, p. 15; M. Beckwith, Hawaiian Mythology, New Haven, 1940, pp. 308-9, 372-3; G. Ashby (ed.), Ever and Always: Micronesian Stories of the Origins of Islands, Landmarks, and Customs, Oregon, 1978, pp. 22-3; J. 
Sanga, 'Remembering', in H. Laracy (ed.), Ples Blong Iumi: Solomon Islands, the Past Four Thousand Years, Suva, 1989, p. 17.

P. D. Nunn, 'Fished Up or Thrown Down: The Geography of Pacific Island Origin-Myths', p. 353-4.

31 Ibid., p. 352.

32 J. Goody and I. Watt, 'The Consequences of Literacy', in Comparative Studies in Society and History, vol. 5, no. 3, April 1963, p. 306.

33 E. Durkheim (J. W. Swain, trans.), The Elementary Forms of the Religious Life, London, 1915, p. 19.

34 A. Brammer, 'Introduction', in A. Brammer (ed.), Displacements: Cultural Identities in Question, Wisconsin, 1994, pp. ix-xii.

35 H. Trevor-Roper, Rise of Christian Europe, London, 1964, p. 9.

36 G. W. F. Hegel, The Philosophy of History, trans. J. Jibree, New York, 1956, p. 93.

37 E. Said, 'Orientalism Reconsidered', in Cultural Critique, no. 1, Autumn 1985, pp. 92 and 101; P. Armstrong, 'Oceanging Craft: The Writing of Contemporary Polynesia', in Landfall, vol. 206, 2003, p. 22.

38 N. Gunson, 'Understanding Polynesian Traditional History', in The Journal of Pacific History, vol. 28, no. 2, 1993, p. 143; B. Finney, 'Myth, Experiment, and the Reinvention of Polynesian Voyaging', in American Anthropologist, new series, vol. 93, no. 2, June 1991, p. 385.

39 N. Gunson, 'Understanding Polynesian Traditional History', p. 143. The works of James Cowan, A. W. Reed, George Grey, Elsdon Best, and S. Percy Smith fall into this category.

40 B. Finney, 'Tracking Polynesian Seafarers', in Science, vol. 137, 28 September 2007, p. 1873.

41 B. Malinowski, Myth in Primitive Psychology, London, 1926, pp. 23, 43.

42 For an extended discussion of these traits in traditional oral societies, see J. Cook-Gumperz and J. J. Gumperz, 'From Oral to Written Culture: The Transition to Literacy', in M. F. Whiteman (ed.), Writing: The Nature, Development and teaching of Written Communication, Volume One: Variation in Writing: Functional and Linguistic Cultural Differences, New Jersey, 1981, pp. 89-94.

43 N. Gunson, 'Understanding Polynesian Traditional History', p. 145.

44 Ibid., p. 147.

45 P. Moon, interview with Hohepa Kereopa, Waimana, December 2003.

46 As in the case of Milton's construction of the idea of God. See J. Carey, Milton, London, 1969, p. 83.

47 C. J. Glacken, Traces on the Rhodian Shore: Nature and Culture in Western Thought from Ancient Times to the End of the Eighteenth Century, Los Angeles, 1990, pp. 4-5. 
48 D. Bidney, 'Myth, Symbolism and Truth', in T. Sebeok (ed.), Myth: A Symposium, Bloomington, 1958, p. 13.

49 R. Piddington, 'A Note on the Validity and Significance of Oral Traditions', in Journal of the Polynesian Society, vol. 65, 1956, p. 202, in B. Finney, 'Myth, Experiment, and the Reinvention of Polynesian Voyaging', p. 385.

50 D. Simmons, The Great New Zealand Myth, Wellington, 1976, p. 321, in B. Finney, 'Myth, Experiment, and the Reinvention of Polynesian Voyaging', p. 385.

51 P. Buck, An Introduction to Polynesian Anthropology, New York, p. 1945, p. 12.

52 R. C. Suggs, The Island Civilizations of Polynesia, New York, 1960, p. 87.

53 C. Richards, 'The Substance of Polynesian Voyaging', p. 218.

54 M. Orbell, Hawaiki: A New Approach to Maori Tradition, Christchurch, 1985, p. 66.

55 B. Finney, 'Myth, Experiment, and the Reinvention of Polynesian Voyaging', p. 383.

56 N. Gunson, 'Understanding Polynesian Traditional History', p. 152.

57 The Political Science Monthly, January 1881, p. 426.

58 M. Eliade, Patterns in Comparative Religion, New York, 1958, p. 419; M. Eliade, 'Methodological Remarks on the Study of Religious Symbolism', in M. Eliade and M. Kitagawa (eds.), The History of Religions: Essays in Methodology, Chicago, 1959, p. 98.

59 One noticeable exception is R. Firth, History and Traditions of Tikopia, Wellington, 1961.

60 As examples, see E. R. Leach, 'Review of a History of Traditions of Tikopia by Raymond First', in Journal of the Polynesian Society, vo. 71, 1962; and A. Hooper, 'Why Tikopia Has Four Clans', Occasional Paper of the Royal Anthropological Institute of Great Britain and Ireland, London, 1981; J. P. Johansen, Studies in Maori Rites and Myths, Copenhagen, 1958, pp. 7-8.

61 M. Orbell, Hawaiki: A New Approach to Maori Tradition, pp. 26-7, in B. Finney, 'Myth, Experiment, and the Reinvention of Polynesian Voyaging', p. 386.

62 See M. Reilly, "In the beginning Was the Word": Tuarangi, Evil Spirits, and Foreign Beings in Mangaian History', in Journal of Pacific History, vo. 28, 1993, pp. 3-14; C. G. Jung, 'On the Psychology of the Trickster-Figure', in Four Archetypes: Mother, Rebirth, Spirit, Trickster, London, 1972, cited in N. Gunson, 'Understanding Polynesian Traditional History', p. 145.

63 G. J. Irwin, 'The Prehistory of Oceania: Colonization and Cultural Change', in A. Sherratt (ed.), The Cambridge Encyclopaedia of Archaeology, Cambridge, 1980, p. 329.

64 R. Taonui, 'Waka Traditions: Some Post-Fleet Considerations', p. 94. 
65 P. D. Nunn, 'On the Convergence of Myth and Reality: Examples from the Pacific Islands', p. 132. This view was also considered in J. E. Terrell and G. I. Irwin, 'History and Tradition in the Northern Solomons: An Analytical Study of the Torau Migration to Southern Bougainville in the Late 1860s', in Journal of the Polynesian Society, vol. 81, 1972, pp. 317-49; R. Shutler and J. S Evrard, Rotuma: A Case of Archaeology Documenting the Rotuman Oral Tradition of the First Tongan Landing', in Man and Culture in Oceania, vol. 7, 1991, pp. 133-37.

66 M. Sahlins, Islands of History, Chicago, 1985, p. 143.

67 L. Melville, cited in N. Gunson, 'Understanding Polynesian Traditional History', p. 149.

68 A. S. Thomson, The Story of New Zealand: Past and Present, Savage and Civilised, vol. 1, London 1859, p. 120.

69 R. M. Kessing, 'Creating the Past: Custom and Identity in the Contemporary Pacific', in D. L. Hanlon and G. M. White (eds.), Voyaging Through the Contemporary Pacific, Oxford, 2000, p. 233. N. Gunson, 'Understanding Polynesian Traditional History', p. 154.

71 P. D. Nunn, 'On the Convergence of Myth and Reality: Examples from the Pacific Islands', p. 125; J. L. T. C. Spence, The Problem of Lemuria, Philadelphia, 1933.

72 H. Hongi (Stowell). 'Recollections', in Northlander, 17 July 1924, in MS papers 62, Alexander Turnbull Library.

73 J. White, The Ancient History of the Maori: His Mythology and Traditions, vol. 1, Wellington, 1887, p. 172

74 Op.cit.; P. Buck, The Coming of the Maori, Wellington, 1949, p. 443; J. G. Frazer, Folklore in the Old Testament, vol. 1, London, 1918 , pp. 250-1.

75 Genesis, chaps. 6-9.

76 J. Macmillan Brown, Maori and Polynesian, London, 1907, p. 138.

77 P. Buck, The Coming of the Maori, p. 443.

78 E. R. Peschel, 'Structural Parallels in Two Flood Myths: Noah and the Maori', in Folklore, vol. 82, no. 2, Summer 1971, p. 120.

79 Ibid., p. 121.

80 N. Turner, in J. G. Turner, The Pioneer Missionary: The Life of the Rev. Nathaniel Turner, Missionary in New Zealand, Tonga, and Australia, London, 1872, p. 167.

81 Genesis 9: 2-3.

82 C. J. Glacken, Traces on the Rhodian Shore, p. 154.

$83 \mathrm{H}$. W. Robinson, Inspiration and Revelation in the Old Testament, Oxford, 1946, p. 8.

84 F. Bacon, The New Atlantis, London, 1627 (New York, 1901), The work was initially published in Latin in 1624 and in English three years later.

85 F. Bacon, The New Atlantis, p. 116. 
86 N. K. Chadwick, 'Notes on Polynesian Mythology', in The Journal of the Royal Anthropological Institute of Great Britain and Ireland, vol. 60, July - December 1930, pp. 442-3.

87 P. Buck, Vikings of the Sunrise, Christchurch, (1938) 1954, pp. 52-66; R. D. Craig, Handbook of Polynesian Mythology, Santa Barbara, 2004, pp. 175-8; N. K. Chadwick, 'Notes on Polynesian Mythology', p. 433.

88 P. Buck, Vikings of the Sunrise, p. 60.

89 S. M. Mead, Landmarks, Bridges and Visions: Aspects of Maori Culture, Wellington, 1997, p. 42.

90 H. A. Brigman, 'Could Climatic Change Have Had an Influence on the Polynesian Migrations?', in Palaeogeography, Palaeoclimatology, Palaeoecology, vol. 41, 1983, p. 193.

91 These reasons are detailed in R. C. Suggs, The Island Civilization of Polynesia, New York, 1960; A. Anderson, 'Islands of Exile: Ideological Motivation in Maritime Migration', in Journal of Island and Coastal Archaeology, vol. 1, issue 1, 2006, pp. 33-47.

92 J. Conrad, The Mirror of the Sea, London, 1916, p. 92.

93 C. J. Glacken, Traces on the Rhodian Shore, p. 12.

94 E. Best, The Maori, vol. 1, Wellington, 1924, p. 153.

95 E. Best, Maori Religion and Mythology, Part 2, Wellington, 1924, p. 39.

96 I. Barber, 'Sea, Land and Fisdh: Spatial Relationships and the Archaeology of South Island Maori Fishing', in World Archaeology, vol. 35, no. 3, 2003, p. 436

97 E. Burke, A Philosophical Enquiry into the Origin of our Ideas of the Sublime and Beautiful, Oxford, 2008, pp. 53-4.

98 J. Mulgan, Report on Experience, p. 4.

99 This effect is discussed in E. Burke, A Philosophical Enquiry into the Origin of our Ideas of the Sublime and Beautiful, p. 68.

100 S. P. Smith, Hawaiki: The Original Home of the Maori, With a Sketch of Polynesian History, Christchurch, 1904, chap. 3.

101 R. Maakreel, 'Imagination and Temporality in Kant's Theory of the Sublime', in The Journal of Aesthetics and Art Criticism, vol. 42, no. 3, Spring 1984, p. 303.

102 J. G. Fichte, The Science of Knowledge, Cambridge, 1982, p. 238.

103 Op. cit.

104 G. W. F. Hegel, W. Cerf \& H. S. Harris (eds.), Faith and Knowledge, New York, 1977, p. 190.

105 F. W. J. Schelling, cited in J. A. Bates, Hegel's Theory of the Imagination, p. 5.

106 R. Maakreel, 'Imagination and Temporality in Kant's Theory of the Sublime', pp. 305, 310.

107 C. Richards, 'The Substance of Polynesian Voyaging', p. 218.

108 D. Lewis, 'Voyaging Stars: Aspects of Polynesian and Micronesian Astronomy', in Philosophical Transactions of the Royal Society, vol. 276, no. 1257, 2 May 1974, pp. 133-148.

109 C. Richards, 'The Substance of Polynesian Voyaging', p. 218. 


\section{Studies, vol. 36, 2000, p. 188. Also see M. Eliade, Patterns in} Studstill, 'Eliade, Phenomenology, and the Sacred', in Religious Comparative Religion, p. 15.

Mairet), New York, 1967, p. 23.

C. J. Glacken, Traces on the Rhodian Shore, p. 15.

L. Thorndike, "The True Place of Astrology in the History of Science', in Isis, vol. 46, 1955, p. 274, in C. J. Glacken, Traces on the Rhodian Shore, p. 16.

C. J. Glacken, Traces on the Rhodian Shore, p. 35.

J. Burstein, 'Victorian Mythography and the Progress of the Intellect', in Victorian Studies, vol. 18, no. 3, March 1975, p. 316.

G. Grote, 'Grecian Legends and Early History', in Westminster Review, vol. 39, 1846, pp. 173-4, in J. Burstein, 'Victorian Mythography and the Progress of the Intellect', p. 317.

L. Strongman, "When earth and sky almost meet": The Conflict between Traditional Knowledge and Modernity in Polynesian Navigation', in Journal of World Anthropology: Occasional Papers: vol. 3, no. 2, November 2009, p. 66; A. Salmond, Their Body is Different, Our Body is Different: European and Tahitian Navigators in the Eighteenth Century', in History and Anthropology, vol. 16, no. 2, 2005, p. 67

P. Buck, Vikings of the Sunrise, p. 65.

I. Barber, 'Sea, Land and Fish: Spatial Relationships and the Archaeology of South Island Maori Fishing', p. 436.

S. Edwards, 'Titiro Whakamuri Kia Marama Ai Te Wao Nei: Whakapapa Epistemologies and Maniapoto Cultural Identities', PhD theses, Massey University, Palmerston North, 2009, p. 183.

J. Conrad, Heart of Darkness, London, 1902, p. 1.

C. Richards, 'The Substance of Polynesian Voyaging', p. 213.

M. Douglas, Purity and Danger: An Analysis of the Concepts of Pollution and Taboo, London, 1994, p. 162; V. Strang, 'Common Senses: Water, Sensory Experience and the Generation of Meaning', in Journal of Material Culture, vol. 10, no. 1, 2005, pp. 92-103.

This issue of the perception of the sacred is examined in $\mathrm{R}$.

M. Orbell, The Natural World of the Maori, p. 137.

M. Eliade, Myth and Reality (trans. Willard R. Trask), New York, 1963, p. 6.

Ibid., pp. 6, 15

Ibid., p. 34.

J. P. Johansen, The Maori and His Religion: In Its Non-Ritualistic Aspects, Copenhagen, 1954, p. 148.

D.Scarr, The History of the Pacific Islands: Kingdom of the Reefs, Melbourne, 1990, p. 6.

E. Best, 'Polynesian Navigators: Their Exploration and Settlement of the Pacific', p. 181. 
131 F. Von Hochstetter, New Zealand: its Physical Geography, Geology, and Natural History: with Special Reference to the Results of Government Expeditions in the Provinces of Auckland and Nelson, Stuttgart, 1867, pp. 202, 207.

132 A. Curnow, 'Landfall in Unknown Seas', in A. Curnow, Collected Poems, 1933 - 1973, Wellington, 1974, pp. 136-9.

133 As an example, see R. S. Wolff, 'Da Gama's Blundering: Trade Encounters in Africa and Asia During the 'European Age of Discovery', 1450-1520', in The History Teacher, vol. 31, no. 3, May 1998, p. 299.

134 L. I. Duperrey, in A. Sharp (ed.), Duperrey's Visit to New Zealand in 1824, Wellington, 1971, pp. 26 ff; R. Cruise, in R. J. Barton, Earliest New Zealand: The Journals and Correspondence of the Rev John Butler, Masterton, 1927, p. 23; T. Shepherd, in H. McDonnell, 'The Rosanna Settlers: with Captain Herd on the Coast of New Zealand 1826-7: including Thomas Shepherd's Journal and his Coastal Views', Wellington, 2002, pp. 33-6; E. Shortland, The Southern Districts of New Zealand: A Journal, With Passing Notice of the Customs of the Aborigines, London, 1851, pp. 39-78.

135 J. McLauchlan, 'The Travel Imagination and the Hybrid Reality in the Wake of Colonialism', Honours Thesis, Colby College, 2006, p. 27.

136 E. B. Fitton, New Zealand: its Present Condition, Prospects and Resources, London, 1856, pp. 39-42.

137 M. L. Pratt, Imperial Eyes: Travel Writing and Transculturation, New York, 1992, p. 6.

138 J. McLauchlan, "The Travel Imagination and the Hybrid Reality in the Wake of Colonialism', p. 27.

139 C. J. Glacken, p. 610.

140 E. Said, Orientalism, London, 1978, p. 79. 